\title{
Fluctuations of Raikot Glacier during the past 70 years: a case study from the Nanga Parbat massif, northern Pakistan
}

\author{
Susanne SCHMIDT, Marcus NÜSSER \\ South Asia Institute, Heidelberg University, D-69120 Heidelberg, Germany \\ E-mail: s.schmidt@sai.uni-heidelberg.de
}

\begin{abstract}
The Himalaya has some of the largest glacier concentrations outside the polar regions. Despite this, long-term measurements detecting the impact of global warming and changing precipitation patterns on glaciers are rare. The Nanga Parbat massif in northern Pakistan is an exception. The cartographer and glaciologist R. Finsterwalder investigated glacier dynamics of this mountain massif in the 1930s, and several other studies document changes since then. The aim of this study is to detect and analyse the changes of Raikot Glacier over the past seven decades. We use a multitemporal and multiscale approach, based on repeat terrestrial images, additional historical data and remotely sensed imagery (Corona, ASTER, Landsat, QuickBird). The multitemporal approach covers the period 1934-2007. While the analyses show a total glacier retreat of $\sim 200 \mathrm{~m}$ in 73 years, this general trend was interrupted by a significant glacier advance between the 1950s and 1980s. Although down-wasting processes can be inferred from an increase in debris-covered area, a general trend of reduced glacier thickness does not appear significant over the whole observation period.
\end{abstract}

\section{INTRODUCTION}

The global debate on glacier dynamics and variations reflects the growing importance of glaciers as water resources, as potential sources of natural hazards originating from glacial lake outbreaks, and their usefulness as indicators of climate change (Solomina and others, 2008). The Little Ice Age glacier retreat has occurred in almost all mountain regions, with increasing rates of ice loss since the mid-1980s (Oerlemans, 2005; Kaser and others, 2006; Zemp and Haeberli, 2007; WGMS, 2008). However, a global assessment of the impact of climate change on glacier fluctuations is very difficult, due to unequal spatial and temporal coverage of records. Long-term glacier monitoring exists for the European Alps and Scandes, but only short-term and limited observations exist in the mountains of Asia (Dyurgerov and Meier, 2005). The complexity of glacier response to climate change is underlined by the fact that several glaciers in the central Karakoram have been expanding since the late 1990s (Hewitt, 2005). Possible reasons for this contrary behaviour are increased precipitation, a local trend of decreasing temperatures, particularly in summer (Fowler and Archer, 2006), or the influence of thick debris coverage which protects the ice against melting (Hewitt, 2005). Because $>42 \%$ of the Himalayan glaciers are debris-covered, it is necessary to analyse their specific ablation conditions in the context of global warming (Iwata and others, 2000). Most debris-covered glaciers show only small retreat rates with some notable exceptions, i.e. Gangotri Glacier in Garhwal, where a $1500 \mathrm{~m}$ retreat has been measured since 1935 (Kumar and others, 2008), and Samadratapu Glacier in Himachal, which has receded $\sim 756 \mathrm{~m}$ since 1963 (Shukla and others, 2009). The debris-covered glaciers are characterized by down-wasting processes (Kargel and others, 2005). Concomitant with glacier decrease, the debris-covered areas increase on most of the glaciers (Iwata and others, 2000). Thick ablation-limiting debris covers are generally confined to the lower and, in the Karakoram, often the smaller fraction of the ablation zone. Thus they protect the lower penetration of glaciers but greatly limit the usefulness of terminus fluctuations and down-wasting as indicators of change in these areas. The larger and, for climate change, more significant factor is the thinly covered and dusty ice of middle to high ablation-zone areas, where debris has the opposite effect of enhancing ablation. This makes summer weather absolutely critical, since it determines both radiative heat flux (cloudiness) and how much dust and dirt accumulates on the ice (Hewitt, 2005, 2009).

Despite the obvious importance of the Himalayan glaciers as water sources for downstream lowlands of south Asia (Viviroli and Weingartner, 2008; Immerzeel and others, 2009) and despite the growing number of local and regional glacier studies, Himalayan glacier response to climate change is poorly known (Zemp and Haeberli, 2007), mainly because long-term and continuous records of glacier fluctuations are almost completely lacking for large tracts of this mountain system (Byers, 2007; Kumar and others, 2008). Mayewski and Jeschke (1979) presented an overview of 112 Himalayan and trans-Himalayan glaciers between 1812 and the 1960s. At present, 310 front-variation series with an average time length of 22 years distributed over the whole of central and south Asia are included by the World Glacier Monitoring Service (WGMS, 2008).

For the Himalaya, the Nanga Parbat massif with its long and relatively continuous glaciological research history dating back to the mid-19th century (Kick, 1967, 1996) represents an important exception and opens comparative research perspectives. During the German expedition to Nanga Parbat in 1934 the first detailed glacier inventory was carried out with an emphasis on Raikot Glacier (Finsterwalder and others, 1935; Finsterwalder, 1938; Kick, 1994). Based on these research results glacier studies in the Nanga Parbat region were repeated 20 and 50 years later (Pillewizer, 1956; Mayewski and Jeschke, 1979; Gardner, 1986; Kick, 1994, 1996).

The aim of our study is to document and analyse the fluctuations and dynamics of Raikot Glacier over the past 70 years. For this purpose, we use a multitemporal and multiscale approach, which is based on historical data, 

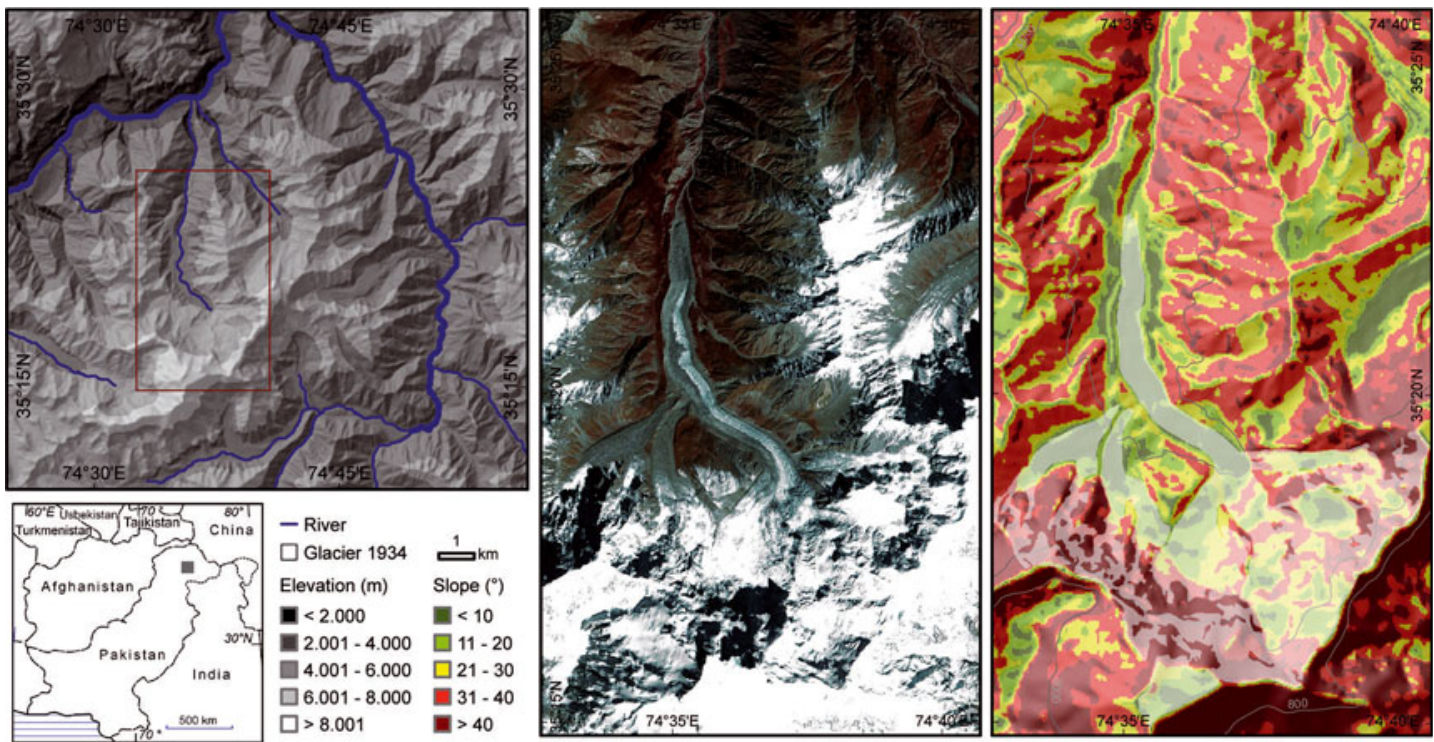

Data Source: DEM (SRTM3 v 4), Landsat ETM (band combination 4-3-2 pan-sharpened), Raikot Glacier in 1934: Topographic map 1:50.000 (1936) Cartography: S. Schmidt (2009)

Fig. 1. Study area: Nanga Parbat region in northern areas of Pakistan (left) and Raikot Glacier at the northern declivity (centre and right); Landsat scene from 2001 showing the Raikot Glacier catchment (centre); glacierized area according to R. Finsterwalder in 1934 combined with a map of slope angle and altitude (right).

repeat photography and satellite imagery, such as Corona, the Advanced Spaceborne Thermal Emission and Reflection Radiometer (ASTER), Landsat and QuickBird.

\section{STUDY AREA}

The Nanga Parbat region is located between $35^{\circ} 10^{\prime} \mathrm{N}$, $74^{\circ} 20^{\prime} \mathrm{E}$ and $35^{\circ} 35^{\prime} \mathrm{N}, 74^{\circ} 55^{\prime} \mathrm{E}$ and the massif constitutes the northwestern limit of the high Himalaya. The maximum elevation difference is from $1030 \mathrm{~m}$ a.s.l. in the Indus Gorge up to the summit of Nanga Parbat ( $8126 \mathrm{~m}$ a.s.l.; Fig. 1). This extreme relief, combined with neotectonic activity, landslides and other mass movements, restricts the glaciated area to $18 \%$ (Kick, 1996). Nevertheless, the massif is one of the most heavily glaciated regions in the western Himalaya (Gardner, 1986).

The regional hydrology is transitional between the monsoonal conditions on the southern declivity of the Himalaya and the deserts of central Asia. A southwest-northeastoriented gradient of decreasing annual precipitation

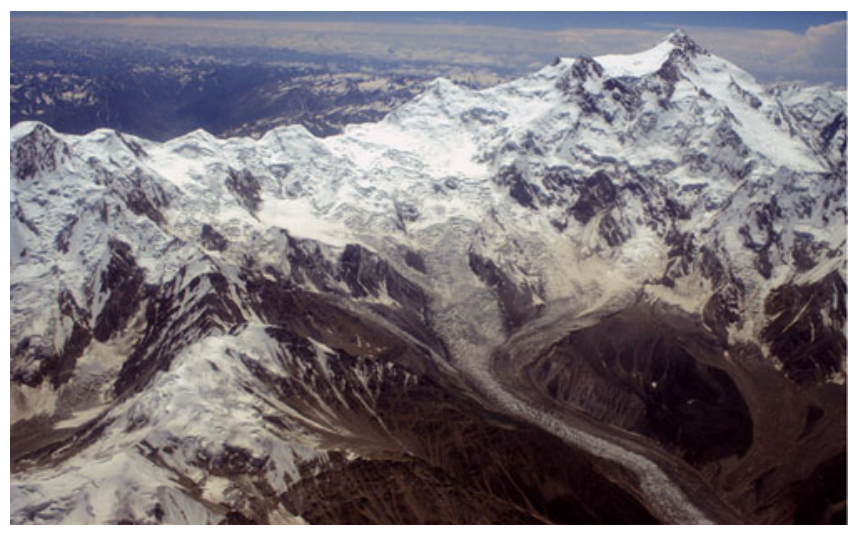

Fig. 2. The north face of Nanga Parbat with Raikot Glacier and its tributaries. (Photo: M. Nüsser, July 1994.) results from differing seasonal circulation systems and orographic conditions (Weiers, 1995). The southern flank of the Nanga Parbat receives higher summer precipitation from monsoonal air masses. The northern and western slopes are more strongly influenced by winter precipitation from westerly disturbances. This horizontal differentiation is overlaid by steep vertical thermo-hygric gradients controlling the seasonal distribution of the snow/rainfall limit and amounts, according to elevation and orientation. In the river valleys, mean annual precipitation is characterized by balanced seasonal distribution, with $126 \mathrm{~mm}$ near Bunji (1372 ma.s.l.) and $516 \mathrm{~mm}$ in Astor (2394 ma.s.l.) (Archer and Fowler, 2004). At 5500 ma.s.l. the amount of precipitation is estimated as $\sim 2300 \mathrm{~mm}$ (Winiger and others, 2005).

Raikot Glacier, on Nanga Parbat's north flank, is $15 \mathrm{~km}$ long and covers $\sim 39 \mathrm{~km}^{2}$, the third largest glacier of the massif. The head of the catchment is delimited by Chongra Peak (6830 ma.s.l.), Raikot Peak (7070 ma.s.l.), Nanga Parbat (8126 ma.s.l.) and Ganalo Peak (6606 ma.s.l.). The ice tongue descends to $3180 \mathrm{~m}$ a.s.l. through large variations in the steepness of the glacier profile, with heavily crevassed zones and seracs alternating with low-gradient portions, such as the Raikot firn above 5200 ma.s.l. (Fig. 2). The glacier is fed mainly by frequent snow and ice avalanches from surrounding steep slopes and high-altitude snowfall (Finsterwalder and others, 1935; Gardner and Jones, 1993).

The ablation zone is $\sim 10 \mathrm{~km}$ long and $\sim 900 \mathrm{~m}$ wide, with a gradient of $<10^{\circ}$. Steep slopes only exist in the upper part of the ablation zone. The lower Raikot icefall between 4000 and $4500 \mathrm{~m}$ a.s.l. has slope angles $>30^{\circ}$. Unlike other large Nanga Parbat glaciers, an almost complete debris cover of varying thickness applies only on the western side and $1.5 \mathrm{~km}$ up-glacier of the terminus (Gardner, 1986; Shroder and others, 2000). In this section, bare ice is only exposed in steep ice facets. Altogether, the proportion of debris-covered to clean ice is $<25 \%$, so Raikot Glacier can be classified as a partly debris-covered glacier. 


\section{RESEARCH HISTORY OF RAIKOT GLACIER}

Unlike most Himalayan glaciers, Raikot and other glaciers of the Nanga Parbat massif have a long and relatively continuous research history (Kick, 1996). The German Himalayan expedition of 1934 carried out a terrestrial photogrammetric survey to make topographic maps with scales of $1: 50000$ and $1: 100000$ (Finsterwalder, 1938), at that time a unique effort for a Himalayan high-mountain massif and a cartographic milestone. These maps represent the Nanga Parbat with the highest spatial accuracy, and provide the basis for all subsequent glaciological research (Gardner and Jones, 1993). Glaciological processes were one of the major research interests of the 1934 expedition, and movement of Raikot Glacier was measured at several cross-sections. Based on these measurements, a slab-like movement divided among distinct ice units, called 'blockschollen' movement, was described for the first time. In addition, the glacier outlines of 1934 were precisely mapped to identify future glacier changes using repeat measurements along the same profiles. Stereophotographs were taken of selected glacier tongues with high spatial resolution, and the camera positions were marked by cairns and on maps (Finsterwalder, 1938). Both the inventory of glacier boundaries and the ice-velocity measurements required very high mapping accuracy, especially regarding the position of glacier termini (Finsterwalder and others, 1935).

These investigations were repeated 20 years later, including velocity-rate measurements and mapping of the terminus (Paffen and others, 1956; Pillewizer, 1956). By 1954, the glacier portal (defined as the portal of the proglacial stream) had retreated $\sim 450 \mathrm{~m}$, and the ice surface $1.5 \mathrm{~km}$ above the terminus had decreased significantly compared to 1934 . By contrast, at $>3500 \mathrm{~m}$ a.s.l. the glacier surface remained nearly the same and was even thicker in some parts than in 1934. Only Chongra Glacier, the eastern tributary of Raikot Glacier, showed significant down-wasting rates between 1934 and 1954. Down-wasting and retreat of the main Raikot Glacier were accompanied by a $30 \%$ increase of velocity along all cross-sections, leading Pillewizer to predict a readvance of the glacier terminus (Paffen and others, 1956; Pillewizer, 1956). Observations in the 1960s suggested there had been a readvance, related to a steepened glacier margin (Kick, 1994).

In 1985 a resurvey of the Raikot Glacier terminus was carried out as part of the Snow and Ice Hydrology Project in the Upper Indus Basin (Gardner, 1986). The investigations confirmed the readvance of the glacier, and the glacier portal was found to be only $160 \mathrm{~m}$ up-glacier from its 1934 position. Average down-wasting, compared to the situation in the 1930s, was estimated at $\sim 9 \mathrm{~m}$ (Gardner, 1986; IDRC/ WAPDA, 1990).

Since the 1980s, investigations at Raikot Glacier have also included supraglacial debris depths and glacial sediment transport (IDRC/WAPDA, 1990; Shroder and others, 2000), ablation rates in relation to debris cover and runoff (Gardner, 1986; Gardner and Jones, 1993), reconstruction of Quaternary glaciations (Kuhle, 1996; Owen and others, 2000; Phillips and others, 2000; Richards and others, 2000) and morphometric analyses of geomorphologic forms and processes (Bishop and others, 2002, 2003). However, relations between glacier terminus changes and quantification of down-wasting intensities have not been studied.

\section{DATA AND METHODS}

To detect and analyse the dynamics of Raikot Glacier, we used a multitemporal and multiscale approach, based on repeat terrestrial photography, historical data and remotesensing data. Conventional satellite data ranging from regional to local scale, (e.g. ASTER, Landsat and QuickBird) allowed monitoring of glacier dynamics and variations since the 1980s. Corona images from the early US militaryreconnaissance satellite widened the time span for detecting changes back to the 1960s. The original topographic maps were used for glacier changes back to 1934. Repeat terrestrial photography made visual comparison possible, to identify fluctuations of the glacier terminus, changes of the ratio between debris-covered and non-debris-covered glacier parts, ice cliffs and vegetation succession in the vicinity of the glacier portal.

\section{Repeat terrestrial photography}

Subject to the availability of historical photographs, the primary goal of re-photographic surveys is to replicate views from the same locations. Comparative interpretation between the original and repeat photography allows detailed assessments of change or persistence of landscape features (Nüsser, 2000, 2001). In recent years, this has been used to detect glacier changes since the late 19th century in the European Alps (Zängl and Hamberger, 2004), the United States (National Snow and Ice Data Center/World Data Center, glacier photograph collection, http://nsidc.org/data/ glacier photo/repeat photography.html) and tropical mountains of Africa and South America (Hastenrath, 2008). However, very few surveys have been undertaken in the mountains of high Asia, particularly with regard to glacier observations. Exceptions include a study by Byers (2007) in the Khumbu Himal, Nepal, where he replicated a set of F. Müller's glacier photographs from 1956, and Kick's (1972, 1989) work on Chogo Lungma, Karakoram.

In the Nanga Parbat region, the large number of photographs taken by members of the expeditions in 1934 (R. Finsterwalder) and 1937 (C. Troll) form a valuable basis for re-photographic surveys (Nüsser, 1998, 2000; Spohner, 2004). For example, Gardner (in 1985) and Nüsser (in 1994 and 2006) repeated Finsterwalder's photograph of the terminus of Raikot Glacier (viewpoint 1B, at $3303 \mathrm{~m}$ ). In 1994 Nüsser repeated a historical image covering the upper ablation and accumulation zone (viewpoint 58A, at $4291 \mathrm{~m}$ ). These multitemporal images enable qualitative detection of glacier variations, including changes in debris cover and ice cliffs, not indicated on the 1934 topographic map.

\section{Satellite images and topographic maps}

In order to improve the quantification of glacier changes geo-rectified data are required. A multi-data approach combining historical maps and data, as well as satellite images, provided near-decadal temporal resolution for detecting and analysing the changes of Raikot Glacier over the past 70 years. As mentioned above, the 1:50000 map of 1934 (Finsterwalder, 1938) is characterized by a high accuracy of contour lines, rivers and glacier margins; however, bare ice is not distinguished from debris-covered ice. Additionally, we used two sketch maps of Raikot Glacier from 1954 (Pillewizer, 1956) and 1985 (Gardner, 1986), plotted on the basis of the primary topographic map from 1934. 
Table 1. Details of (a) applied satellite images and (b) topographic maps

(a) Applied satellite images

\begin{tabular}{lccccc}
\hline Source & Data & Scale & Size & Number of GCPs & $\begin{array}{c}\text { RMS } \\
\mathrm{m} \mathrm{km}^{2}\end{array}$ \\
& & & & \\
& & & $35.4 \times 46.9$ & 12 & 10.2 \\
Finsterwalder (1938) & 1934 & $1: 50000$ & $6.7 \times 14.3$ & 14 & 18.2 \\
Pillewizer (1956) & 1954 & & $2.1 \times 3.2$ & 10 & 7.9
\end{tabular}

(b) Topographic maps

\begin{tabular}{|c|c|c|c|c|c|c|}
\hline Sensor & $\begin{array}{c}\text { Date } \\
\mathrm{dd} / \mathrm{mm} / \mathrm{yy}\end{array}$ & $\begin{array}{l}\text { Spatial resolution } \\
\qquad \mathrm{m}\end{array}$ & Spectral resolution & $\begin{array}{l}\text { Size } \\
\mathrm{km}^{2}\end{array}$ & Number of GCPs & $\begin{array}{l}\text { RMS } \\
\text { pixel }\end{array}$ \\
\hline Corona & $15 / 09 / 71$ & $\sim 1.8 \mathrm{~m}$ in the centre & Panchromatic & $8 \times 19$ & & \\
\hline Landsat TM & 15/10/92 & 28.5 & VIS + IR & $180 \times 180$ & 60 & 0.4 \\
\hline Landsat TM & $17 / 11 / 98$ & 28.5 & $\mathrm{VIS}+\mathrm{IR}$ & $18 \times 180$ & 41 & 0.5 \\
\hline ASTER & 24/08/01 & 15 & VIS & $40 \times 40$ & $9^{*}$ & 0.9 \\
\hline Landsat ETM & 09/10/01 & $\begin{array}{c}15 \\
28.5\end{array}$ & $\begin{array}{c}\text { Panchromatic } \\
\text { VIS + IR }\end{array}$ & $180 \times 180$ & Base image & \\
\hline Landsat ETM & 03/10/02 & $\begin{array}{c}15 \\
28.5\end{array}$ & $\begin{array}{c}\text { Panchromatic } \\
\text { VIS + IR }\end{array}$ & $180 \times 180$ & 55 & 0.44 \\
\hline QuickBird & 19/07/03 & $\begin{array}{l}0.6 \\
2.4\end{array}$ & $\begin{array}{l}\text { Panchromatic } \\
\text { VIS + NIR }\end{array}$ & $3.7 \times 12.4$ & $1.3^{*}$ & 1.3 \\
\hline QuickBird & 05/09/06 & $\begin{array}{l}0.8 \\
2.8\end{array}$ & $\begin{array}{l}\text { Panchromatic } \\
\text { VIS + NIR }\end{array}$ & $8.2 \times 25.5$ & $1.8^{*}$ & 1.8 \\
\hline ASTER & 18/11/07 & $\begin{array}{l}15 \\
30\end{array}$ & $\begin{array}{l}\text { VIS } \\
\text { IR }\end{array}$ & $40 \times 40$ & $7^{*}$ & 0.8 \\
\hline
\end{tabular}

\footnotetext{
* Orthorectified images.

Notes: GCPs: ground control points; RMS: root-mean square error; ETM: Enhanced thematic Mapper; VIS: visible; IR: infrared.
}

The earliest cloudless satellite scene is from the US Corona sensor, dated 1971, a panchromatic image that fills the gap between 1954 and 1985. In the 1970s,conventional remote-sensing data became available and, since the 1980s, Landsat TM (Thematic Mapper) data with a spatial resolution of $30 \mathrm{~m} \times 30 \mathrm{~m}$ (Hall and others, 2003; Kääb and others, 2005). High spatial resolution QuickBird data, starting from 2000, allow the detection of glacier outlines with high accuracy, and also small-scale ice cliffs and ponds on the glacier. The temporal resolution of satellite images for glacial analysis is generally restricted by clouds and seasonal snow cover. To minimize snow-covered areas, which complicate differentiation between glaciated and non-glaciated areas, the best images are those at the end of the ablation season, before the first snowfall event. Due to these restrictions, altogether nine satellite images - one Corona (1971), four Landsat TM (1992, 1998, 2001 and 2002), two ASTER (2001 and 2007) and two QuickBird (2003 and 2006) datasets were chosen for detailed analysis (Table 1 ).

\section{Geometric correction of satellite images and maps}

Change-detection analysis requires spatial registration of selected multitemporal datasets. To ensure the required spatial accuracy, and to solve the problem of non-available ground control points (GCPs), all satellite images (as well as the topographic maps) were matched to one selected 'base' image: the georeferenced Landsat scene from 2001 (projected in UTM, WGS84, downloaded from the US Geological Survey). This allows visual comparison between the image and stream as well as ridgelines calculated by means of a $30 \mathrm{~m} \times 30 \mathrm{~m}$ resampled digital elevation model (DEM) from the Shuttle Radar Topography Mission (SRTM-3, version 4, downloaded from http://srtm.csi.cgiar.org). This ensured we had sufficient spatial accuracy. To improve the coherence between the co-registered Landsat data and the base image, many well-distributed tie points are required. For this purpose, we used the automatic Förstner operator implemented in the programme ENVI 4.5. This operator can detect points in images which correspond to corners (defined as points where two or more lines intersect) as well as centre points of circular symmetric patterns, such as dots or circles (Förstner, 1986). The automatically determined tie points were controlled manually, and noncorresponding points were deleted, as well as points located on unstable terrain on and around the glacier. This resulted in the three Landsat scenes each being matched to the base image for $>50$ tie points. The scanned topographic map (projected on the Everest ellipsoid, Gauss-Krüger system) from 1934 was georeferenced with 12 well-distributed and distinctive GCPs selected on the Landsat image. Due to the small sections of both sketch maps from 1954 and 1985 (covering solely Raikot Glacier), both maps were registered with $>10$ tie points to the georeferenced topographic map from 1934. Subsets of the high-resolution ASTER and QuickBird images were orthorectified using $>5$ GCPs from the base image. The corresponding altitude data were derived from the DEM. Visual comparison of all datasets revealed the necessary high spatial accuracy.

\section{Mapping of glacier boundaries}

The Raikot Glacier margins and portal were delineated for the whole dataset. Common automatic glacier mapping 

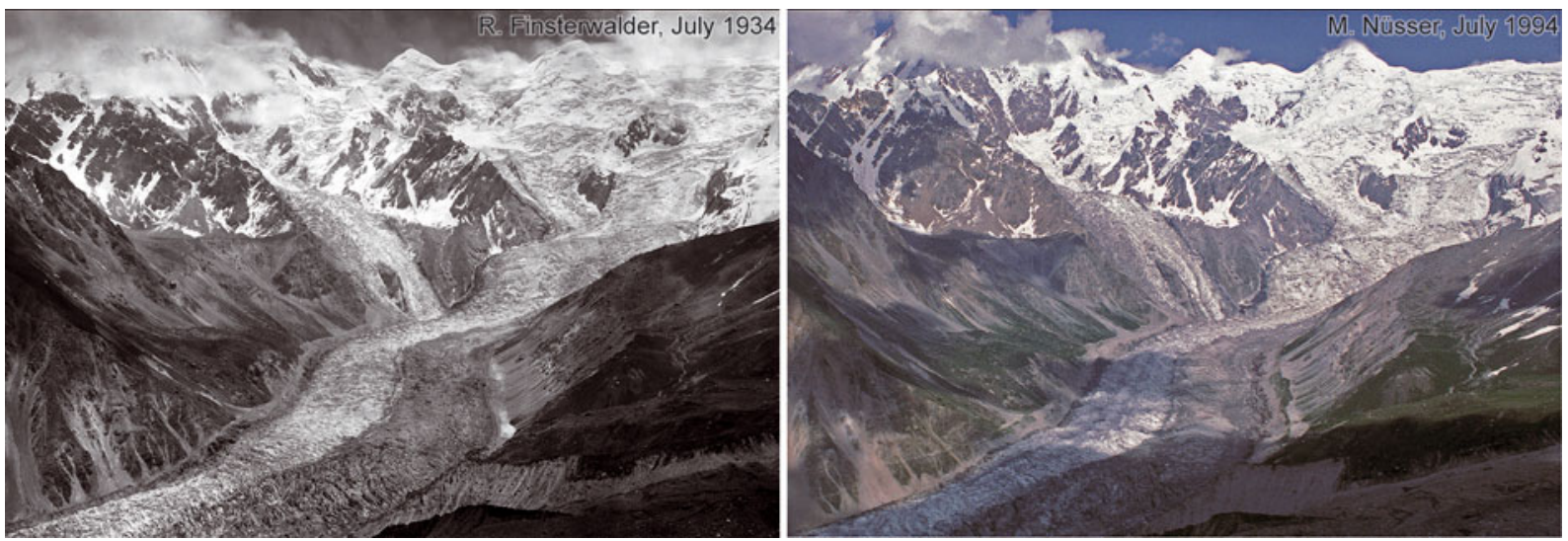

Fig. 3. Repeat terrestrial photographs of the upper part of Raikot Glacier from 1934 and 1994.

approaches apply spectral differences between ice, characterized by high albedo values, and surrounding vegetation and rocks, identifiable by relatively low reflectivity (Paul, 2002). Due to the spectral homogeneity of the surfaces, such automatic approaches cannot be applied to debris-covered glacier tongues. Instead, semi-automatic approaches using morphometric parameters (e.g. slope, curvature and ridge) were developed to map scree-covered glacier termini (Paul and others, 2004; Bolch and Kamp, 2005; Buchroithner and Bolch, 2007). For Raikot Glacier the limited availability of DEMs for each time period to be analysed restricts the use of a semi-automatic approach, and the glacier margin and portal were manually digitized on-screen on all satellite images and maps using ArcGIS 9.2. The manual delineation of glacier outlines achieves the highest accuracy, reaching an error rate of $<2 \%$ (Bolch and others, 2008). To increase the temporal resolution of remote-sensing data, images of different spatial resolution were used to delineate glacier boundaries. If the spatial resolution of the satellite images varies between 5 and $30 \mathrm{~m}$, only minor errors occur (Paul, 2003).

\section{Measurements of glacier length}

Changes in glacier length were quantified following the classical measure concept of Forel (1895). For this purpose, a baseline $460 \mathrm{~m}$ long was plotted parallel to the glacier front. Distances between this baseline and the glacier terminus were derived within intervals of $10 \mathrm{~m}$ for each period using ArcGIS 9.2. The position of the glacier outline in 1934 was set as the benchmark. Forel's concept considers different recession rates in various sections of an irregularshaped glacier front. In addition, the up- and down-glacier shift of the portal was measured on those images and maps where it was clearly detectable. All later positions of the glacier portal were measured in order to continue the earlier approaches used in the historical studies. Only the $y$ values of the digitized portals were determined, and the differences between their spatial positions were calculated to exclude corresponding lateral shifts due to the northfacing glacier tongue.

\section{Detection of debris-covered areas}

Down-wasting trends of glaciers are generally characterized by an increase in debris-covered areas on the glacier surface resulting from melting processes (Iwata and others, 2000; Bolch and others, 2008). To assess this for Raikot Glacier, the ablation zone was classified into the categories of bare and scree-covered ice using an automatic segmentation approach. It was based on ratio mages derived from Landsat TM3 and TM5, with an accuracy of $>97 \%$ (Paul and others, 2002). To enhance the temporal resolution, we also applied this approach using two ASTER images and band $3(15 \mathrm{~m}$ resolution) and band $4(30 \mathrm{~m}$ resolution), with band 4 resampled to a pixel size of $15 \mathrm{~m}$ using bilinear interpolation. The application of ASTER ratio images revealed no significant differences to corresponding work based on Landsat TM (Kääb and others, 2003). Thus, in total six satellite images (1992, 1998, two 2001, 2002 and 2007) were used to determine changing proportions of debris-covered and bare ice.

\section{RESULTS AND DISCUSSION}

\section{Glacier-change detection using repeat terrestrial photography}

The Raikot icefall and firn, as well as the eastern tributary (Chongra Glacier), are shown in the background of the first pair of repeat photographs taken at $4291 \mathrm{~m}$ a.s.I. in the years 1934 and 1994 (Fig. 3). Shown in the foreground is the lowgradient and debris-covered ice confined to the left side above $3700 \mathrm{~m}$ a.s.I. In the right foreground the steep lateral moraines and the debris-covered tongue of Ganalo Glacier are visible. The steep slopes are affected by frequent snow and ice avalanches which are important for glacier feeding. In both years the patchy snow cover redistributed by avalanches shows similar features. The size and number of non-glaciated areas along steep rock faces have not significantly increased in the 60 years between photographs. The terminus of the tributary, Chongra Glacier, shows some retreat, but no significant decrease of the glacier surface can be detected. In conclusion, variations $>3700 \mathrm{~m}$ a.s.l. prove to be minor between 1934 and 1994 .

The second sequence of repeat photographs, from the locality of Fairy Meadows (3300 ma.s.I.), involves four images from 1934, 1985, 1994 and 2006. They show the debris-covered glacier terminus $\sim 3200$ ma.s.l. (Fig. 4). At this relatively low elevation the lateral moraines are covered with montane conifer forests of Pinus wallichiana and Picea smithiana. The inner slopes of the moraines are occupied by Hedysarum falconeri (Dickoré and Nüsser, 2000). Throughout this period the fence shown at the bottom right corner has separated cultivated land from the pasture of the summer settlement. Overall, visual comparison indicates relatively 

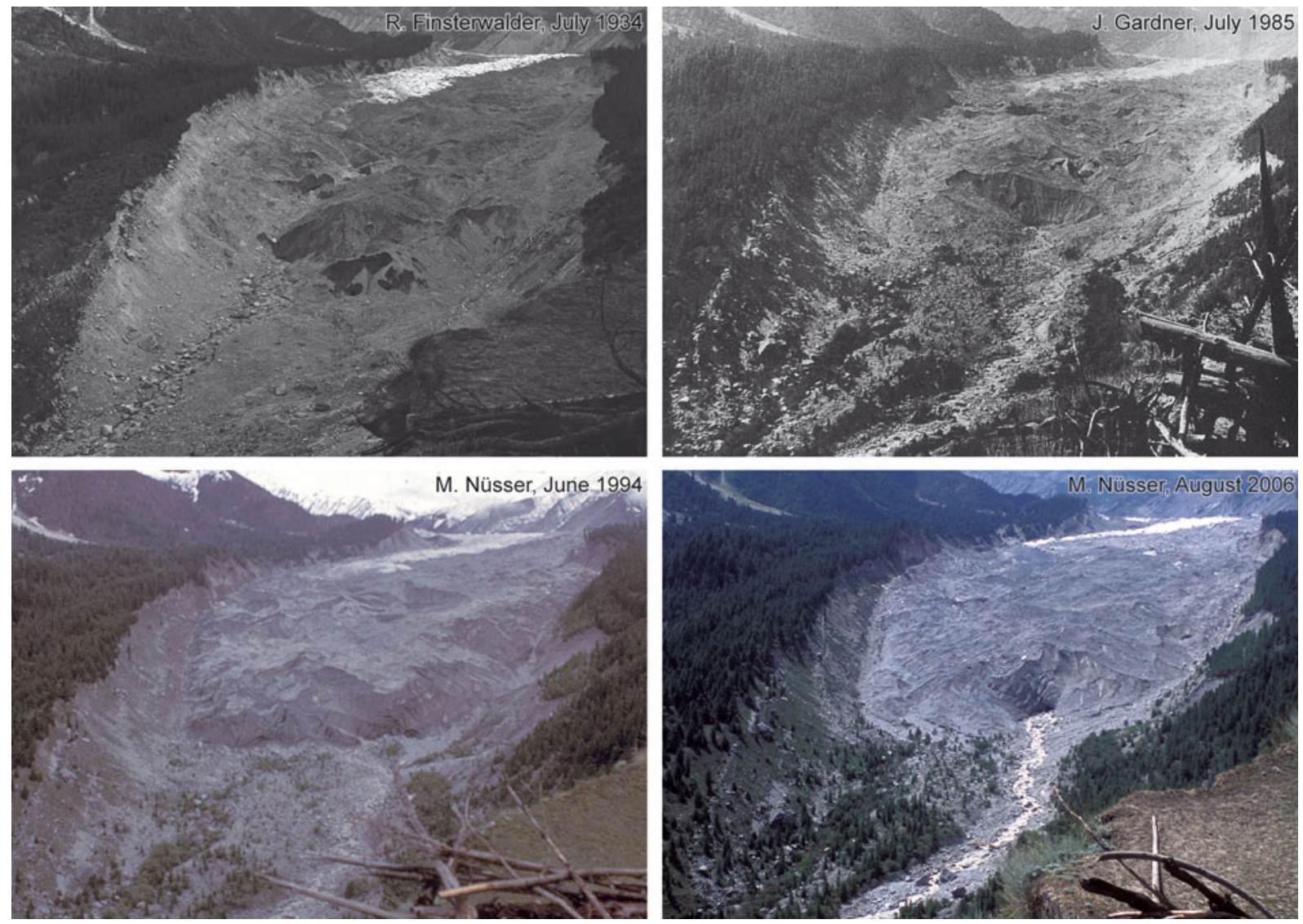

Fig. 4. Repeat terrestrial photography of the glacier front between July 1934 and August 2006.

small rates of recession and surface changes over the last seven decades.

In 1934, the farthest extent of the irregular-shaped tongue was on the western flank and the glacier portal was on the eastern side. Ice cliffs of varying dimensions were exposed on the debris-covered tongue. Furthermore, the distinctive band of clean ice is visible in the upper part of the image. The second image, for 1985, shows a marked retreat (Gardner, 1986). At that time, the farthest extent of a glacier lobe was on the eastern side and the glacier portal and subglacial channel had shifted to the western side. As in 1934, the glacier tongue is debris-covered and ice is only exposed in cliffs that have decreased in number. In the proglacial area a substantial colonization by vegetation can be observed, mainly coniferous trees.

In the 1994 image, no significant retreat of the glacier margin can be detected in comparison with 1985. However, the thickness of the glacier tongue varies in different places. Compared to 1985, the debris-covered terminus has steepened markedly on the front and western side and new large ice cliffs have appeared. According to Shroder and others (2000) this trend continued at least until 1996. On the 1994 image one can detect a more regular terminal lobe. In 2006 the portal had retreated by backward incision into the glacier, but the proglacial river is in nearly the same place as in 1985. One can detect a significant expansion of the montane forest on the lateral moraines of the receding Raikot Glacier. Along the proglacial stream floor, a succession of hygrophilous Salix sericocarpa and Myricaria germanica bushes is detectable (Dickoré and Nüsser, 2000). Given that some well-defined large boulders remain in the same position in 2006 as in 1934, one can assume a high stability of the proglacial area and lateral moraines. This casts doubt on the catastrophic break-out flood from four new portals in 1993 or 1994 suggested by Shroder and others (2000). Our own field visits in 1993, 1994 and 1995 did not verify such an event.

\section{Glacier-front variation}

The comparative analyses of historical maps, data and satellite images combined with geographical information systems allow us to quantify the changes of the glacier terminus (Figs 5 and 6; Table 2). Finsterwalder's (1938) topographic map shows the irregular-shaped glacier tongue in 1934. The farthest extent of ice was located at the western side at $3155 \mathrm{~m}$ a.s.l., and this ice lobe reached $\sim 125 \mathrm{~m}$ further north than the portal, located at $3176 \mathrm{~m}$ a.s.I. On the sketch map showing the glacier outline in 1954 (Pillewizer, 1956) the glacier terminus has retreated significantly and altered in shape. The largest ice lobe at the glacier front, $\sim 300 \mathrm{~m}$ long, has migrated from west to east. According to Pillewizer (1956), the glacier portal was relocated to $3210 \mathrm{~m}$ a.s.I. in 1954. Its total retreat between 1934 and 1954 was $450 \mathrm{~m}\left(23 \mathrm{~m} \mathrm{a}^{-1}\right)$, a value which coincides with our digital distance measurements. During this time the average rate of retreat for the whole glacier front is calculated as $385 \mathrm{~m}\left(19 \mathrm{~m} \mathrm{a}^{-1}\right)$.

By contrast, the glacier portal advanced $\sim 300 \mathrm{~m}$ between 1954 and 1985. Gardner's (1986) estimate of $200 \mathrm{~m}$ portal advance after 1954 is based on a miscalculation. The mean advancing rate of the glacier front amounted to $\sim 228 \mathrm{~m}$ $\left(7 \mathrm{~m} \mathrm{a}^{-1}\right)$ for this time period. Based on the 1971 Corona image, a continuous advance of the glacier terminus can be assumed. However, due to low-contrast differences in the proglacial area on this image, only the ice cliff at the glacier 


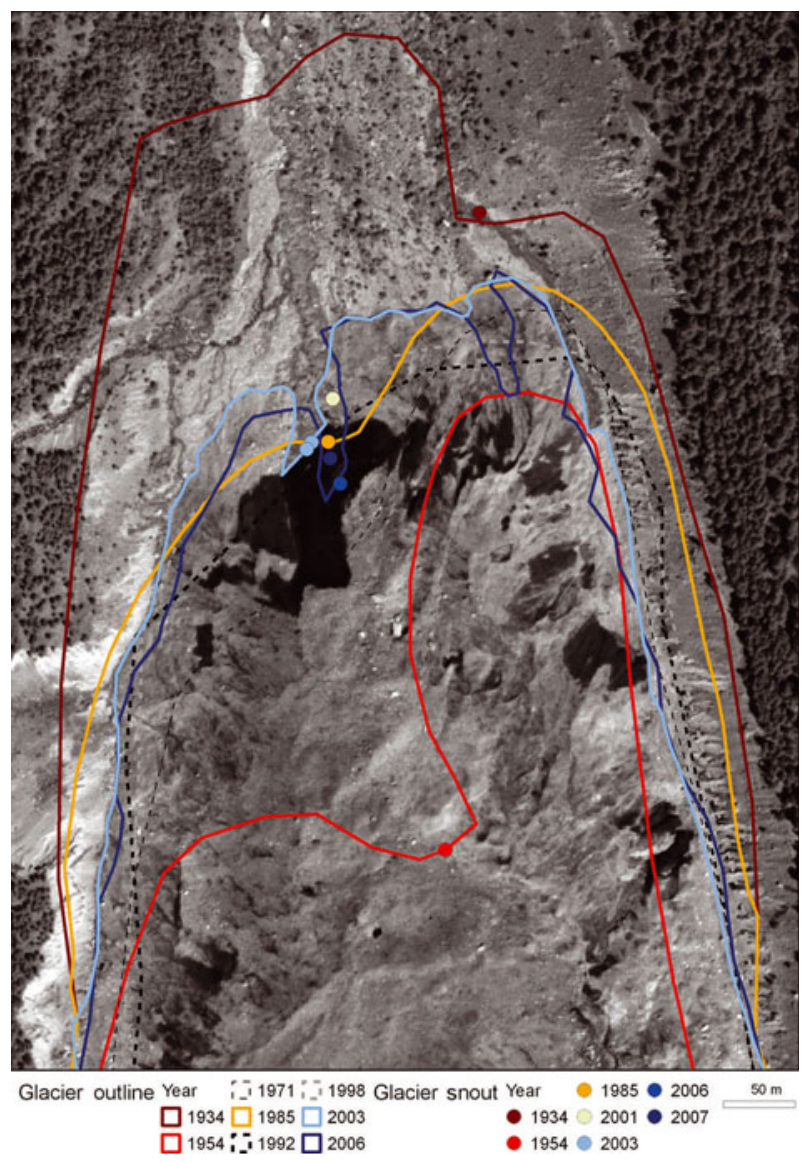

Fig. 5. Variation of glacier front and portal between 1934 and 2006. (Mapped on QuickBird image, July 2003.)

front is clearly detectable. Significant down-glacier movement of the ice cliff on the western side also suggests an advance on the eastern side between the positions of 1954 and 1985. The location of the ice cliff indicates an advance of the glacier terminus of $>113 \mathrm{~m}$ between 1954 and 1971 and a further down-glacier movement of $105 \mathrm{~m}$ between 1971 and 1985. Therefore, the possibility of a single surge event, as described for various tributaries of Panmah Glacier, Karakoram (Hewitt, 2007), can be excluded for Raikot Glacier. The advancing rate between 1954 and 1985 corresponds with the observed reaction of some other Himalayan glaciers for this period (WGMS, 2008).

The pan-sharpened QuickBird images from 2003 and 2006 provide very detailed pictures of the glacier terminus.

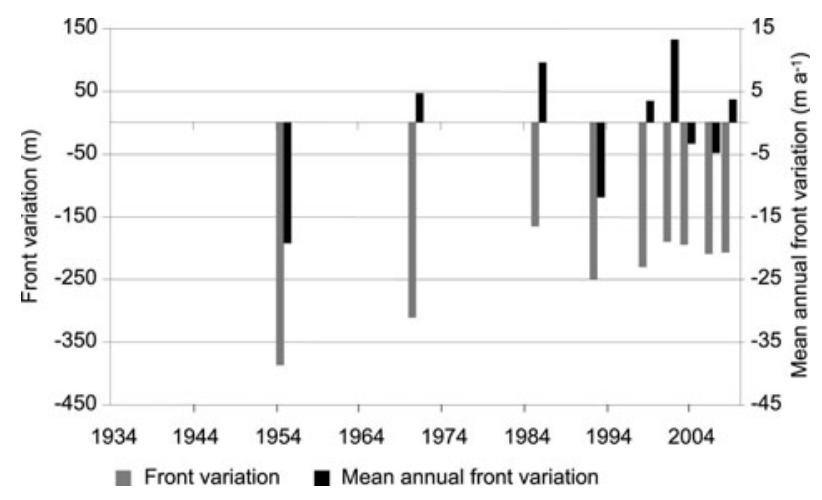

Fig. 6. Total front variation (relative to 1934) and mean annual front variation (relative to previous observation) of Raikot Glacier related to the glacier position of 1934 .

In contrast to the irregular-shaped glacier terminus and onesided ice lobes in 1934, 1954 and 1985, one can detect a regular-shaped lobe in 2003 . The portal was only $5 \mathrm{~m}$ upglacier from its position in 1985, and retreat of the whole glacier front amounted to only $30 \mathrm{~m}$. Closer inspection of the front variation indicates remarkable fluctuations between 1985 and 2003. Between 1985 and 1992 the glacier front retreated $\sim 84 \mathrm{~m}\left(-12 \mathrm{~m} \mathrm{a}^{-1}\right)$, but by 2001 had readvanced $\sim 60 \mathrm{~m}\left(7 \mathrm{~m} \mathrm{a}^{-1}\right)$. The low spatial resolution of the 1992 Landsat image results in a reduced spatial accuracy of the mapped glacier margin. Nevertheless, compared to 1985 a glacier retreat can be clearly observed.

In 2006 a break-up of the terminus into three lobes can be identified. Despite this, the eastern side is nearly in the same position as in 2003, whereas a significant retreat is detectable on the western side. In total, the last 3 years of the analyses show a $15 \mathrm{~m}$ decrease of the whole terminus. The portal receded $25 \mathrm{~m}$ up-glacier and shifted slightly to the eastern side (Fig. 8).

These small fluctuations of the glacier terminus between the 1980s and 2006 contrast with the dominant and large retreats in other parts of the Himalaya since the 1980s (WGMS, 2008). However, Raikot Glacier shows a similar response to the Karakoram 'anomaly' described by Hewitt (2005) for the neighbouring mountain system. Baltoro Glacier in the cenrtal Karakoram, however, has oscillated back and forth a few hundred metres between 1913 and 2004. The total terminus recession amounts to only $65 \mathrm{~m}$, which reflects a quite stable snout position (Smiraglia and others, 2007). Thus, the fluctuations of Baltoro Glacier are very similar to those of Raikot Glacier.

Table 2. Variation of glacier front and portal between 1934 and 2007

\begin{tabular}{|c|c|c|c|c|c|c|c|c|c|}
\hline & 1954 & 1971 & 1985 & 1992 & 1998 & 2001 & 2003 & 2006 & 2007 \\
\hline \multicolumn{10}{|l|}{ Front variation } \\
\hline relating to $1934(\mathrm{~m})$ & -385.2 & -271.3 & -166.3 & -250.1 & -228.9 & -189.4 & -196.4 & -211.0 & -207.2 \\
\hline relating to previous observation (m) & -385.2 & +113.9 & +105.0 & -83.8 & +21.2 & +39.5 & -7.0 & -14.6 & +3.8 \\
\hline mean annual variation $\left(\mathrm{m} \mathrm{a}^{-1}\right)$ & -19.3 & +7.2 & +7.0 & -11.98 & +3.5 & +13.2 & -3.5 & -4.9 & +3.8 \\
\hline \multicolumn{10}{|l|}{ Variation of glacier portal* } \\
\hline relating to $1934(\mathrm{~m})$ & -450 & - & -160 & - & - & -130 & -165 & -190 & -170 \\
\hline relating to previous observation (m) & -450 & - & +290 & - & - & +30 & -35 & -25 & +20 \\
\hline mean annual variation $\left(\mathrm{m} \mathrm{a}^{-1}\right)$ & -22.5 & - & +9.4 & - & - & +1.9 & -17.5 & -8.3 & +20 \\
\hline
\end{tabular}

* Up-glacier measured distance. 


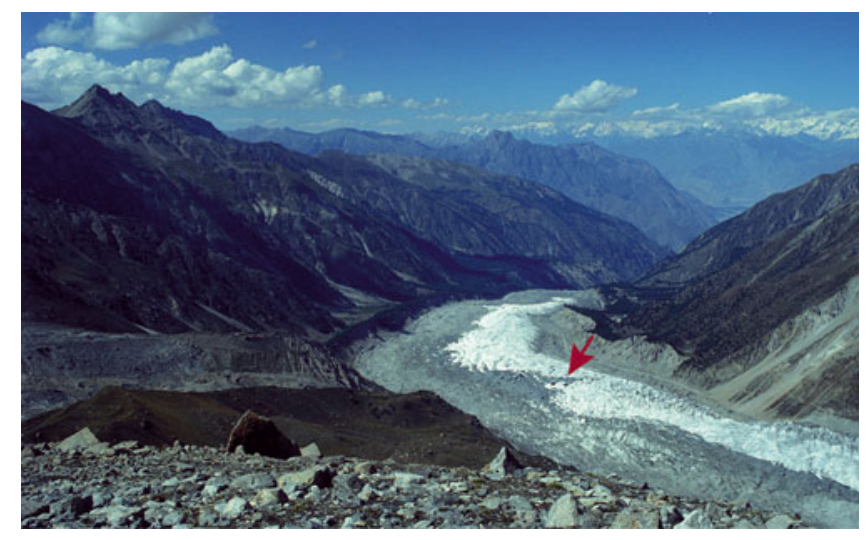

Fig. 7. Triangular debris accumulation on Raikot Glacier. (Photo: M Nüsser, June 1993.)

\section{Variation of debris-covered areas}

Comparing 2003 and 2006 shows the details of changes on the glacier tongue (Fig. 8). A large number of small water ponds up to $1200 \mathrm{~m}^{2}$ in area existed on the debris-covered terminus in 2003, but had partly disappeared 3 years later. The number of ice cliffs and thin debris-covered areas decreased between 2003 and 2006. A corresponding increase of debris-covered areas can also be detected in the classified Landsat and ASTER images over the last two decades.

On the western side of Raikot Glacier, one remarkable feature is a distinct triangular-shaped debris accumulation, visible in all images since 1992 (Figs 7 and 9). This clear feature, covering an area of $\sim 0.108 \mathrm{~km}^{2}$, was not shown in the sketch of debris thickness measured in 1985 (Mattson and Gardner, 1989; IDRC/WAPDA, 1990). However, this marked surface feature can be dated back to the late 1980s or early 1990s. Landsat data from July 1990 suggest the causative event in a landslide deposit forming a first debris
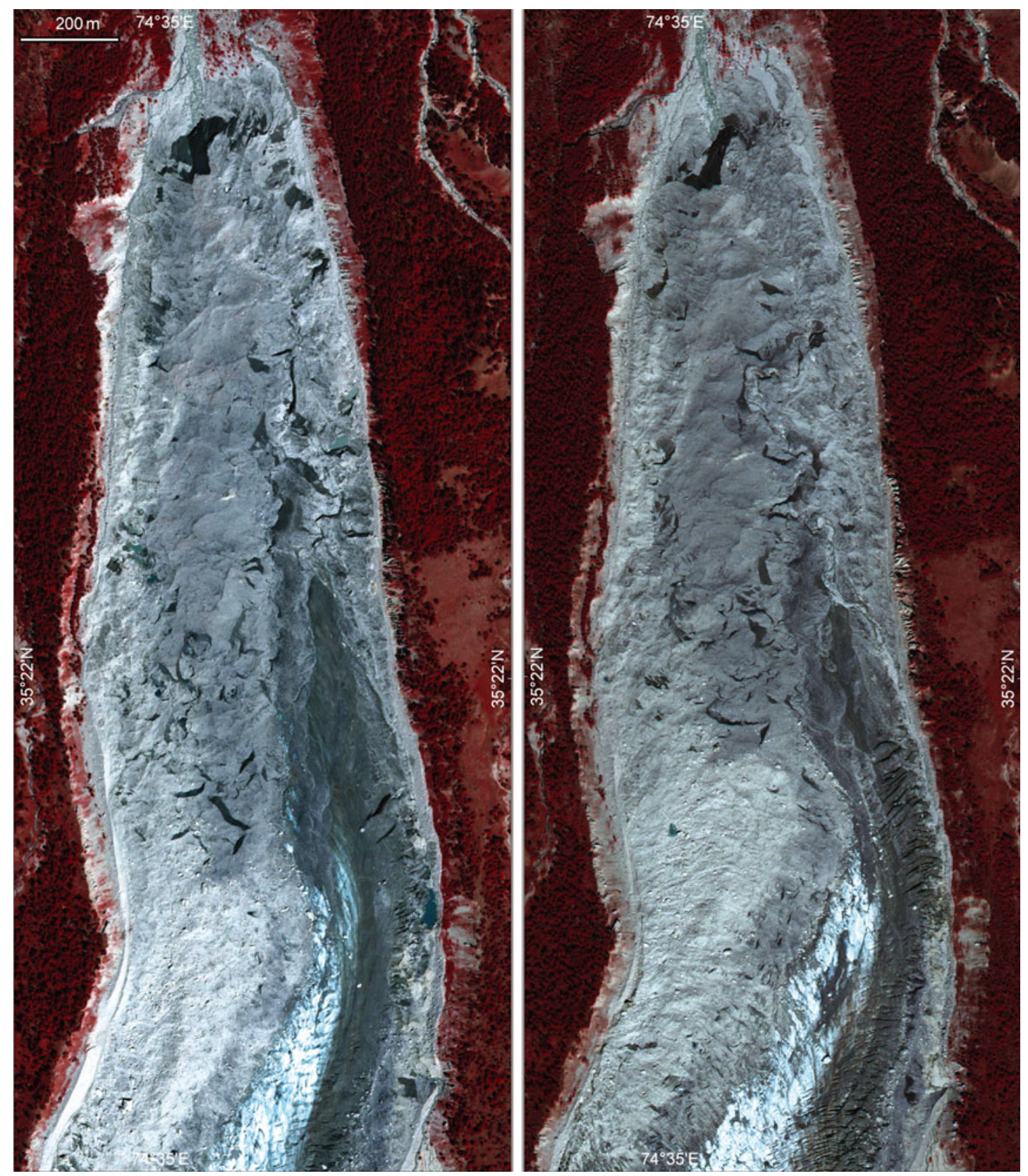

Fig. 8. Bi-temporal comparison of the Raikot Glacier between July 2003 (left) and September 2006 (right) (pan sharpened QuickBird-images, band combination: 4-3-2). 


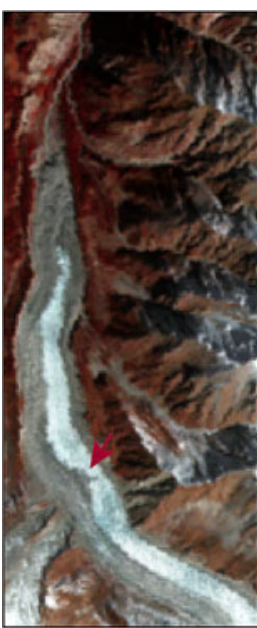

Landsat TM

15 Sep. 1992

17 Nov 1998
24 Aug. 2001

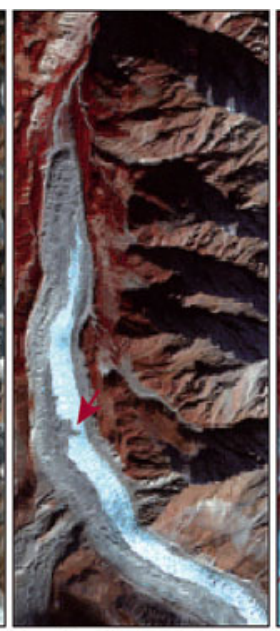

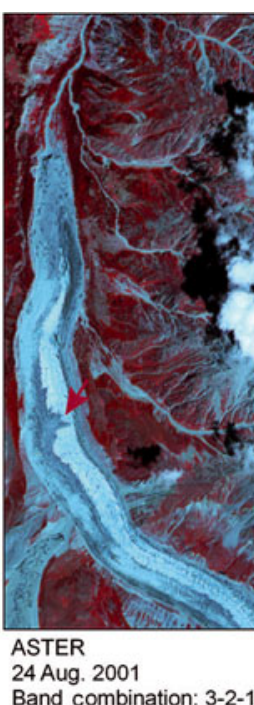

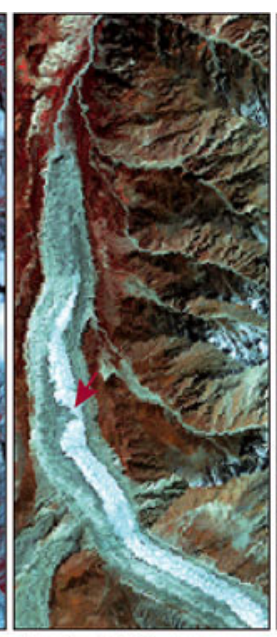

Landsat ETM 9 Oct. 2001

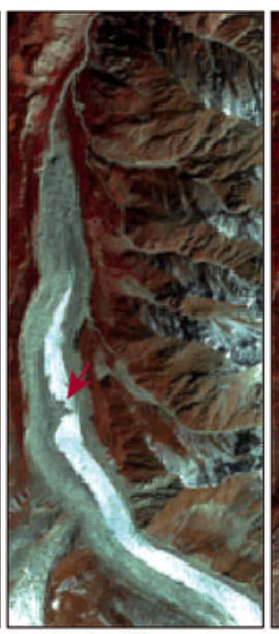

Landsat ETM

3 Oct. 2002

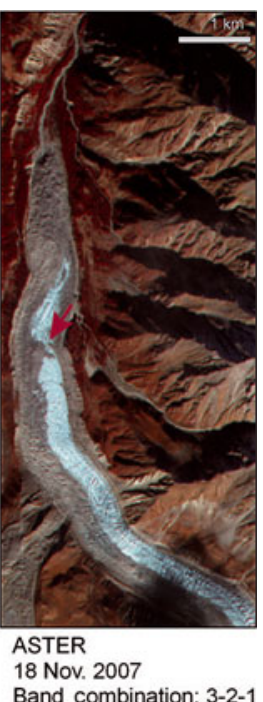

Fig. 9. Raikot Glacier dynamics between 1992 and 2007.

accretion at the junction of Raikot and Ganalo Glaciers. This striking debris accumulation has steadily moved $\sim 1.8 \mathrm{~km}$ between 1992 and 2007 (Fig. 9).

To minimize the effect of different seasonal snowcover distributions, shadow effects and cloud cover, the spatio-temporal analyses of debris-covered areas have been restricted to the lower part of the ablation zone, $<3900$ ma.s.l., and up to $7.6 \mathrm{~km}$ above the terminus. This section has an area of $\sim 5.1 \mathrm{~km}^{2}$ (13\% of the total glacier), and the surface has been classified into debris-covered and bare ice. In this section, the area of clean ice was $2.04 \mathrm{~km}^{2}$ $(39 \%)$ in 1992 and had decreased to $1.81 \mathrm{~km}^{2}(35 \%)$ in 2007, a decrease of $0.56 \%$ in relation to the whole glacierized area $\left(39 \mathrm{~km}^{2}\right)$. The slight decrease of bare ice (Fig. 10) might indicate only a slight down-wasting trend for Raikot Glacier. According to Gardner (1986), the glacier surface was lowered $\sim 9 \mathrm{~m}$ between 1934 and 1985. These results contrast to the observed more-pronounced downwasting rates of debris-covered glaciers elsewhere in the Himalaya. For example, on Khumbu Glacier a significant increase of debris-covered areas, $\sim 2.5 \%\left(0.06 \% \mathrm{a}^{-1}\right)$, has been measured between 1962 and 2005 (Bolch and others, 2008). However, the observed results are quite similar to Karakoram glaciers in the middle decades of the 20th century. There are conflicting reports on this for the Karakoram, but most of the glaciers draining the highest watersheds have shown thickening in the debris-covered areas since 1999 (Hewitt, 2005, 2009).

\section{CONCLUSION AND OUTLOOK}

Similarly to most debris-covered glaciers in the northwest Himalaya and in the nearby Karakoram, Hindu Kush and Kun Lun ranges, Raikot Glacier shows only minor retreating rates since the 1980s. Glacier fluctuations over the past 70 years are characterized by retreat between the 1930s and 1950s, a marked advance between the 1950s and 1980s, and a relatively stable situation after 1992 . It remains to be seen to what degree these fluctuations can be interpreted as a response to climate change, such as through increased precipitation and lower summer temperatures as described by Archer and Fowler (2004), or through increased thickness of debris cover on ice, which in turn protect the glacier against ablation (Hewitt, 2005). Due to the historical database, from the 1930s, 1950s and 1980s, our investigations need to be expanded to the whole Nanga Parbat massif in order to gain an adequate understanding of glacier response to global climate change and to reduce existing data gaps in the western Himalaya. In this context, we intend to take velocity measurements and compare them to those carried out in 1934 (Finsterwalder, 1938), in the 1950s (Pillewizer, 1956; Kick, 1994), 1980s (Gardner and Jones, 1993; Kick, 1994) and 1990s (Shroder and others, 2000) and to glacier down-wasting rates on selected glaciers of the Nanga Parbat massif.

\section{ACKNOWLEDGEMENTS}

This paper is a revised version of an oral presentation at the European Geosciences Union in 2008. Field surveys in the 1990s were generously supported by the German Research Foundation (Deutsche Forschungsgemeinschaft) and in 2006 by the South Asia Institute, University of Heidelberg. The authors are indebted to U. Kamp (University of Montana) for access to ASTER satellite data. We gratefully acknowledge

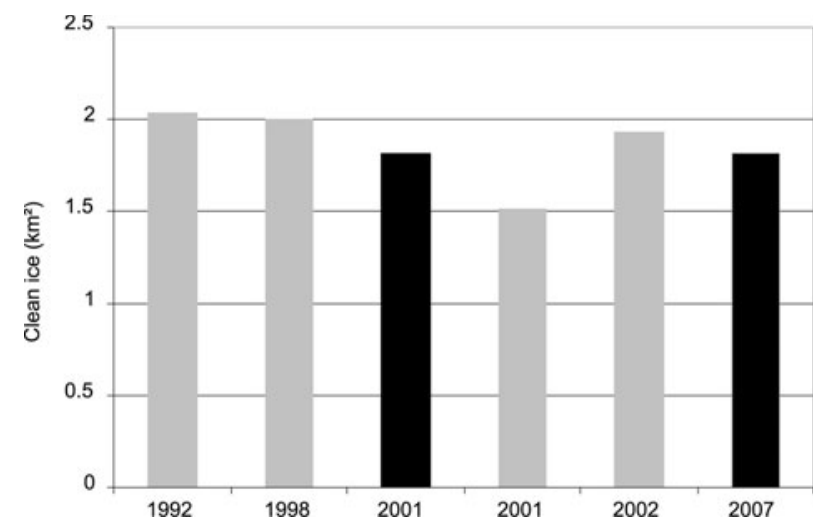

Fig. 10. Variation of clean ice in the lower ablation zone of Raikot Glacier. (Light grey bars derived from Landsat images; dark grey bars derived from ASTER images.) 
the substantial and fruitful comments of J. Gardner, K. Hewitt and an anonymous reviewer. We also thank P. Roden for proofreading.

\section{REFERENCES}

Archer, D.R. and H.J. Fowler. 2004. Spatial and temporal variations in precipitation in the Upper Indus Basin: global teleconnections and hydrological implications. Hydrol. Earth Syst. Sci., 8(1), 47-61.

Bishop, M.P., J.F. Shroder, R. Bonk and J. Olsenholler. 2002. Geomorphic change in high mountains: a western Himalayan perspective. Global Planet. Change, 32(4), 311-329.

Bishop, M.P., J.F. Shroder and J.D. Colby. 2003. Remote sensing and geomorphometry for studying relief production in high mountains. Geomorphology, 55(1-4), 345-361.

Bolch, T. and U. Kamp. 2005. Glacier mapping in high mountains using DEMs, Landsat and ASTER data. Grazer Schr. Geogr. Raumforsch., 41, 37-48.

Bolch, T., M. Buchroithner, T. Pieczonka and A. Kunert. 2008. Planimetric and volumetric glacier changes in the Khumbu Himal, Nepal, since 1962 using Corona, Landsat TM and ASTER data. J. Glaciol., 54(187), 592-600.

Buchroithner, M.F. and T. Bolch. 2007. An automated method to delineate the ice extension of the debris-covered glaciers at $\mathrm{Mt}$ Everest based on ASTER imagery. Grazer Schr. Geogr. Raumforsch., 43, 71-78.

Byers, A.C. 2007. An assessment of contemporary glacier fluctuations in Nepal's Khumbu Himal using repeat photography. Himalayan J. Sci., 4(6), 21-26.

Dickoré, W.B. and M. Nüsser. 2000. Flora of Nanga Parbat (NW Himalaya, Pakistan). An annotated inventory of vascular plants with remarks on vegetation dynamics. Berlin, Botanischer Garten und Botanisches Museum. (Englera 19.)

Dyurgerov, M.B. and M.F. Meier. 2005. Glaciers and the changing Earth system: a 2004 snapshot. Boulder, CO, University of Colorado. Institute of Arctic and Alpine Research. (INSTAAR Occasional Paper 58.)

Finsterwalder, R. 1938. Die geodätischen, gletscherkundlichen und geographischen Ergebnisse der Deutschen Himalaja-Expedition 1934 zum Nanga Parbat. Berlin, Karl Siegismund Vlg.

Finsterwalder, R., W. Raechl, P. Misch and F. Bechtold. 1935. Forschung am Nanga Parbat. Deutsche Himalaya-Expedition 1934. Hannover, Helwing.

Forel, F.A. 1895. Les variations périodiques des glaciers: discours préliminaires. Arch. Sci. Phys. Natur. [Génève], 34, 209-229.

Förstner, W. 1986. A feature based correspondence algorithm for image matching. Int. Arch. Photogramm., 26(3/3), 150-166.

Fowler, H.J. and D.R. Archer. 2006. Conflicting signals of climatic change in the Upper Indus Basin. J. Climate, 19(17), 4276-4293.

Gardner, J.S. 1986. Recent fluctuations of Rakhiot Glacier, Nanga Parbat, Punjab Himalaya, Pakistan. J. Glaciol., 32(112), 527-529.

Gardner, J.S. and N.K. Jones. 1993. Sediment transport and yield at the Rakhiot Glacier, Nanga Parbat, Punjab Himalaya. In Shroder, J.F., ed. Himalayas to the sea: geology, geomorphology and the Quaternary. London, Routledge, 184-197.

Hall, D.K., K.J. Bayr, W. Schöner, R.A. Bindschadler and J.Y.L. Chien. 2003. Consideration of the errors inherent in mapping historical glacier positions in Austria from ground and space (1893-2001). Remote Sens. Environ., 86(4), 566-577.

Hastenrath, S. 2008. Recession of equatorial glaciers: a photo documentation. Madison, WI, Sundog Publishing.

Hewitt, K. 2005. The Karakoram anomaly? Glacier expansion and the 'elevation effect', Karakoram Himalaya. Mt. Res. Dev., 25(4), 332-340.

Hewitt, K. 2007. Tributary glacier surges: an exceptional concentration at Panmah Glacier, Karakoram Himalaya. J. Glaciol., 53(181), 181-188.
Hewitt, K. 2009. Rock avalanches that travel onto glaciers and related developments, Karakoram Himalaya, Inner Asia. Geomorphology, 103(1), 66-79.

Immerzeel, W.W., P. Droogers, S.M. de Jong and M.F.P. Bierkens. 2009. Large-scale monitoring of snow cover and runoff simulation in Himalayan river basins using remote sensing. Remote Sens. Environ., 113(1), 40-49.

International Development Research Centre, Canada and Pakistan Water and Power Development Authority (IDRC/WAPDA). 1990. Overall report, snow and ice hydrology project, Upper Indus basin. Waterloo, Ont., Wilfred Laurier University, Cold Regions Research Centre.

Iwata, S., T. Aoki, T. Kadota, K. Seko and S. Yamaguchi. 2000. Morphological evolution of the debris cover on Khumbu Glacier, Nepal, between 1978 and 1995. IAHS Publ. 264 (Symposium at Seattle, 2000 - Debris-Covered Glaciers), 3-11.

Kääb, A. and 6 others. 2003. Glacier monitoring from ASTER imagery: accuracy and application. EARSeL eProc., 2(1), 43-53.

Kääb, A. and 10 others. 2005. Remote sensing of glacier- and permafrost-related hazards in high mountains: an overview. Natur. Hazards Earth Syst. Sci. (NHESS), 5(4), 527-554.

Kargel, J.S. and 16 others. 2005. Multispectral imaging contributions to global land ice measurements from space. Remote Sens. Environ., 99(1-2), 187-219.

Kaser, G., J.G. Cogley, M.B. Dyurgerov, M.F. Meier and A. Ohmura. 2006. Mass balance of glaciers and ice caps: consensus estimates for 1961-2004. Geophys. Res. Lett., 33(19), L19501. (10.1029/2006GL027511.)

Kick, W. 1967. Schlaginweits Vermessungsarbeiten am Nanga Parbat 1856. Deut. Geodat. Komm. Bayer. Akad. Wiss. 97.

Kick, W. 1972. Auswertung photographischer Bilder für die Untersuchung und Messung von Gletscheränderungen: mit Beispielen aus dem Kaukasus und dem Karakorum. Z. Gletscherkd. Glazialgeol., 8(1-2), 147-167.

Kick, W. 1989. Bericht 1989 über das Chogo-LungmaGletscherende im Karakorum. Z. Gletscherkd. Glazialgeol., 25(1), 139-145.

Kick, W. 1994. Gletscherforschung am Nanga Parbat, 1856-1990. Wiss. Alpenver. 30.

Kick, W. 1996. Forschung am Nanga Parbat. Geschichte und Ergebnisse. In Kick, W., ed. Forschung am Nanga Parbat. Geschichte und Ergebnisse. Berlin, Geographisches Institut der Technische Universität Berlin, 1-134. (Beitr. Mat. Reg. Geogr. 8.)

Kuhle, M. 1996. Rekonstruktion der maximalen eiszeitlichen Gletscherbedeckung im Nanga-Parbat-Massiv $\left(35^{\circ} 05^{\prime}-40^{\prime} \mathrm{N} /\right.$ $\left.74^{\circ} 20^{\prime}-75^{\prime} \mathrm{E}\right)$. In Kick, W., ed. Forschung am Nanga Parbat. Geschichte und Ergebnisse. Berlin, Geographisches Institut der Technische Universität Berlin, 135-156. (Beitr. Mat. Reg. Geogr. 8.)

Kumar, K., R.K. Dumka, M.S. Miral, G.S. Satyal and M. Pant. 2008. Estimation of retreat rate of Gangotri glacier using rapid static and kinematic GPS survey. Current Sci., 94(2), 258-262.

Loewe, F. 1961. Glaciers of Nanga Parbat. Pakistan Geogr. Rev., 16(1), 19-24.

Mattson, L.E. and J.S. Gardner. 1989. Energy exchange and ablation rates on the debris-covered Rakhiot Glacier, Pakistan. Z. Gletscherkd. Glazialgeol., 25(1), 17-32.

Mayewski, P.A. and P.A. Jeschke. 1979. Himalayan and transHimalayan glacier fluctuations since A.D. 1812. Arct. Alp. Res., 11(3), 267-287.

Nüsser, M. 1998. Nanga Parbat (NW-Himalaya): naturräumliche Ressourcenausstattung und humanökologische Gefügemuster der Landnutzung. Bonn. Geogr. Abh. 97.

Nüsser, M. 2000. Change and persistence: contemporary landscape transformation in the Nanga Parbat Region, Northern Pakistan. Mt. Res. Dev., 20(4), 348-355.

Nüsser, M. 2001. Understanding cultural landscape transformation: a re-photographic survey in Chitral, eastern Hindukush, Pakistan. Landscape Urban Plan., 57(3-4), 241-255. 
Oerlemans, J. 2005. Extracting a climate signal from 169 glacier records. Science, 308(5722), 675-677.

Owen, L.A., C.H. Scott and E. Derbyshire. 2000. The Quaternary glacial history of Nanga Parbat. Quat. Int., 65-66, 63-79.

Paffen, K.H., W. Pillewizer and H.J. Schneider. 1956. Forschungen im Hunza-Karakorum. Vorläufiger Bericht über die wissenschaftlichen Arbeiten der Deutsch-Österreischen HimalayaKarakorum-Expedition 1954. Erdkunde, 20(1), 1-33.

Paul, F. 2002. Changes in glacier area in Tyrol, Austria, between 1969 and 1992 derived from Landsat Thematic Mapper and Austrian glacier inventory data. Int. J. Remote Sens., 23(4), 787-799.

Paul, F. 2003. The new Swiss glacier inventory 2000: application of remote sensing and GIS. (PhD thesis, University of Zürich.)

Paul, F., A. Kääb, M. Maisch, T. Kellenberger and W. Haeberli. 2002. The new remote-sensing-derived Swiss glacier inventory: I. Methods. Ann. Glaciol., 34, 355-361.

Paul, F., C. Huggel and A. Kääb. 2004. Combining satellite multispectral image data and a digital elevation model for mapping debris-covered glaciers. Remote Sens. Environ., 89(4), 510-518.

Phillips, W.M., V.F. Sloan, J.F. Shroder, P. Sharma, M. Clarke and H.M. Rendell. 2000. Asynchronous glaciation at Nanga Parbat, northwestern Himalaya Mountains, Pakistan. Geology, 28(5), 431-434.

Pillewizer, W. 1956. Der Rakhiot-Gletscher am Nanga Parbat im Jahre 1954. Z. Gletscherkd. Glazialgeol., 3(2), 181-194.

Richards, B.W., L.A. Owen and E.J. Rhodes. 2000. Timing of Late Quaternary glaciations in the Himalayas of northern Pakistan. J. Quat. Sci., 15(3), 283-297.

Shroder, J.F., M.P. Bishop, L. Copland and V.F. Sloan. 2000. Debriscovered glaciers and rock glaciers in the Nanga Parbat Himalaya, Pakistan. Geogr. Ann., 82A(1), 17-31.

Shukla, A., R.P. Gupta and M.K. Arora. 2009. Estimation of debris cover and its temporal variation using optical satellite sensor data: a case study in Chenab basin, Himalayas. J. Glaciol., 55(191), 444-452.

Smiraglia, C., C. Mayer, C. Mihalcea, G. Diolaiuti, M. Belò and G. Vassena. 2007. Ongoing variations of Himalayan and Karakoram glaciers as witnesses of global changes: recent studies on selected glaciers. In Baudo, R., G. Tartari and E. Vuillermoz, eds. Mountain witnesses of global changes. Amsterdam, Elsevier, 235-248.

Solomina, O., W. Haeberli, C. Kull and G. Wiles. 2008. Historical and Holocene glacier-climate variations: general concepts and overview. Global Planet. Change, 60(1-2), 1-9.

Spohner, R. 2004. Rezente Landschaftsveränderungen im Nanga Parbat-Gebiet (Nordwest-Himalaya). (PhD thesis, University of Bonn.)

Viviroli, D. and R. Weingartner. 2008. 'Water tower' - a global view of the hydrological importance of mountains. In Wiegandt, E., ed. Mountains: sources of water, sources of knowledge. Dordrecht, Springer, 15-20.

Weiers, S. 1995. Zur Klimatologie des NW-Karakorum und angrenzender Gebiete. Statistische Analysen unter Einbeziehung von Wettersatellitenbildern und eines Geographischen Informationssystems (GIS). Bonn Geogr. Abh. 92.

Winiger, M., M. Gumpert and H. Yamout. 2005. Karakorum Hindukush - western Himalaya: assessing high-altitude water resources. Hydrol. Process., 19(12), 2329-2338.

World Glacier Monitoring Service (WGMS). 2008. Global glacier changes: facts and figures, ed. Zemp, M., I. Roer, A. Kääb, M. Hoelzle, F. Paul and W. Haeberli. Geneva, World Glacier Monitoring Service/United Nations Environment Programme.

Zängl, W. and S. Hamberger. 2004. Gletscher im Treibhaus: eine fotografische Zeitreise in die alpine Eiszeit. Steinfurt, Tecklenborg.

Zemp, M. and W. Haeberli. 2007. Glaciers and ice caps. In Eamer, J., ed. Global outlook for ice and snow. Nairobi, United Nations Environment Programme, 115-152. 